\title{
EFFICACY OF SUPPLEMENTATION OF PHYTASE ENZYME TO BROILER DIETS WITH OR WITHOUT DI-CALCIUM PHOSPHATE ON PERFORMANCE AND ECONOMIC APPRAISAL
}

\author{
Madyan M. A. Alshamiri ${ }^{1}$; Syada A. M. Ali ${ }^{2}$; Hyder O. Abdalla ${ }^{2}$;
} Hatim B. A. Elkheir ${ }^{2}$

${ }^{1}$ Dep. of Anim. Sci., Fac. of Agric. Sci., Uni. of Gezira, Sudan. Rese. in the Dep. of Poultry Res., Agric. Res. and Ext. Auth., Taiz, Yemen.

${ }^{2}$ Dep. of Anim. Sci., Fac. of Agric. Sci., Uni.of Gezira, Sudan.

Corresponding author: Syada A. M. Ali ${ }^{2}$ Email: saydamhmmd@yahoo.com Received: 12/04/2021

Accepted: 31/05/2021

ABSTRACT: One hundred and eight male one-day age broiler chicks (Ross 308) were used in a 42-day experiment with objectives to study the effect of supplementing phytase with or without added di-calcium phosphate (DCP) to broiler chickens' diets on their performance, carcass characteristics and economic appraisal. The birds were allocated to three treatments in a completely randomized design (CRD) with three replicates each. Treatment one T1 (control), fed basal diets supplemented with $+0.1 \%$ DCP were used, treatment two T2 (basal diet supplemented with 1500 FTU/Kg phytase $+0.1 \% \mathrm{DCP}$ ) and treatment three T3 (basal diet supplemented with $1500 \mathrm{FTU} / \mathrm{Kg}$ ). Results showed significant $(\mathrm{P} \leq 0.05)$ differences in feed consumption $(\mathrm{FC})$, body weight (BW), body weight gain (BWG) and feed conversion ratio (FCR), where $\mathrm{T} 3$ recorded the best results. Some gastrointestinal tract (GIT) organs (esophagus, proventriculus, small and large intestine, liver and caeca) and abdominal fat pads were significantly $(\mathrm{P} \leq 0.05)$ different in their weights; but no significant $(\mathrm{P} \geq 0.05)$ differences in gizzards and hearts weights. There were significant $(\mathrm{P} \leq 0.05)$ differences in lengths of proventriculus, small and large intestines; no significant $(\mathrm{P} \geq 0.05)$ differences were found in lengths of esophagus and caeca. There were significant $(\mathrm{P} \leq 0.05)$ differences in meat chemical properties, (DM\%, Ash\%, EE\%, Ca\% and $\mathrm{P} \%$ ) of the breast muscle. However, no significant $(\mathrm{P} \geq 0.05)$ differences in meat sensory traits (taste, flavor color and tenderness) and mortality rates were found. Significant $(\mathrm{P} \leq 0.05)$ differences were found in tibia bone chemical and physical properties (weight, length, thickness of the medial wall, the lateral wall and the medullary canal diameter) and chemical composition of manure where $\mathrm{T} 3$ had the best results. The economics appraisal recorded significant $(\mathrm{P} \leq 0.05)$ differences where $\mathrm{T} 3$ had the least cost and highest revenue. The results reveal that using $(1500 \mathrm{FTU} / \mathrm{Kg})$ phytase without adding DCP is the best for performance parameters and economic appraisal and reduced environmental pollution.

Key words: phytase; broiler performance; di-calcium phosphate; economic appraisal. 
Madyan M. A. Alshamiri ${ }^{1}$ et al.

\section{INTRODUCTION}

The poultry production industry is facing challenges due to the high costs of feed materials, which account to $70 \%$ of the overall production (Alagawany and Attia, 2015). Phosphorus is the second abundant mineral after calcium in the animal body (NRC, 1994). Phosphorus is more complicated than just maintaining the bone structure of animals. It has numerous other physiological functions that can be affected by deficiency of $\mathrm{P}$ (Selle, and Ravindran 2007). They added that sequences as a result of the failure in providing sufficient levels of $\mathrm{P}$ can be detrimental to the physiological prosperity of the bird and resulting in financial losses. However, the availability and quantity of dietary $\mathrm{P}$ are of vital importance for the growing mono-gastric animals. In plants seeds, phosphorus is stored in the form of phytate which encompasses about two thirds of total plant P (Hughes et al., 2009). They reported that phytate $\mathrm{P}$ in poultry is usually utilized with availability of 0 to $50 \%$, affected by the age and metabolic adaptability in critical circumstances. A large percentage of dietary phosphorus that is unavailable to animals is trashed as manure resulting in critical hazards to the environment (Mondal et al., 2007). In order to meet the requirements of phosphorus to poultry, inorganic phosphate is usually added to the poultry feeds, which lead to the problem of environmental pollution because a large amount of phosphorus is excreted in the poultry manure (Khan et al., 2013). Phytases are phosphor-hydrolases that initiate the process removal of phosphorus from phytate. These enzymes are widely used in animal feeds to improve the available phosphorus and to reduce phosphorus pollution to the environment from animal waste (Lei, and Porres, 2003). Scholey et al. (2018) proposed that using high doses of phytase to replace inorganic $\mathrm{P}$ had the potential to reduce the costs of feeds. They suggested further investigations are required to evaluate the impact of replacing inorganic $\mathrm{P}$ with phytase doses greater than 1000 FTU/kg feed. Srikanthithasan et al. (2020) concluded that broiler fed diets that were supplemented with phytase and were deficient in phosphorus, showed better growth performance and tibia development from (1-35 day of age). Adding phytase to broiler rations had beneficial effects on growth and mineralization of tibia bones but did not affect the carcass traits (Ciurescu et al., 2020). Supplementing phytase at 1500 FTU/kg showed a clear ability to boost broiler performance by improving FCR. The use of phytase enhanced 45-d processing yields, increased tender yields relative to carcass weights, and reduced fat pad weights (Ennis et al., 2020). Phytase improved the BWG and FCR of growing ducks and reduced the level of $\mathrm{Zn}$ in duck excreta (Attia et. al., 2019). They revealed that adding phytase in low $\mathrm{P}$ diets showed significant $(\mathrm{P} \leq 0.05)$ effects on $\mathrm{Ca}$ and $\mathrm{P}$ retention in bones. Phytases are enzymes have been widely utilized in animal feeding specifically poultry to enhance phosphorus intake and minimize environmental pollution (Daniel et al., 2018). The present experiment was carried out with a general objective to study the effects of supplementing broiler chickens diets with phytase enzyme with or without added DCP on broiler performance. Specific objectives were to study the effect of these diets on the gastrointestinal tract (GIT), carcass characteristics, tibia bones, economical appraisal, and manure 


\section{phytase; broiler performance; di-calcium phosphate; economic appraisal.}

chemical properties that are hazard to the environment.

\section{MATERIAL AND METHODS}

An experiment was conducted with one hundred and eight (108) eight-day age broiler male chicks (Ross 308) and was randomly distributed into three treatments (each treatment with three replicates). A completely randomized design of 12 chicks in each replicate was used. The chicks were randomly housed in the experimental pens in a deep litter floor poultry house of $\left(1.5^{\mathrm{m} 2}\right)$ for each pen. The environmental condition inside the house was controlled and the chicks were reared under good management conditions with continuous access to feed, water and light. The diets used in this experiment were prepared and formulated in accordance with the recommendations of the National Research Council (NRC, 1994) for broiler chicks. These diets are shown in Table (1) for both production phases (starter and finisher). The chickens were fed a starter diet during the period of second - third week of age on ad libitum basis. A finisher diet was then offered from fourth - sixth week of age on $a d$ libitum basis. These diets were off as follows:

Treatment (T1) or (control) basal diets for both phases of feeding (starter and finisher) without added phytase enzyme using $0.1 \%$ di calcium phosphate (DCP).

Treatment (T2) the basal diets as in T1 plus phytase enzyme (1500 FTU/ kg feed) Treatment (T3) the basal diets plus phytase enzyme (1500 FTU/ kg feed) but without including DCP to the diets.

According to AOAC (2000) one phytase unit (FTU) was defined as the amount of phytase enzyme releasing $1 \mu \mathrm{mol}$ of inorganic orthophosphate from a sodium phytate substrate $83 /$ minute at a temperature of $37^{\circ} \mathrm{C}$ and $\mathrm{pH} 5.5$.

Feed for each replicate was weighed and offered daily and at the end of the week, feed left was collected and weighed to get the actual feed consumption per week in grams $(\mathrm{g})$. The weights of the birds were taken weekly and average body weight and body weight gain (g) were calculated for each replicate. Furthermore, the weekly feed conversion ratio (FCR) for each replicate was calculated as the ratio of weekly feed intake to weekly body weight gain and as an overall FCR at the end of the experiment, The Mortality of birds was recorded when there were deaths among birds and the weekly mortality

After 42 days (experimental rate was calculated and as an overall at the termination of the experiment termination), nine birds of average body weight from each treatment (three from each replicate) were selected. The birds from each replicate were sacrificed on Islamic Tradition (Ali, et al., 2011), for further evaluation of carcass characteristics and sensory evaluation of meat. After feathers removal and evisceration the weight of the hot carcass was taken and then cooled and its cold weight was recorded as well. Some carcass parts (breasts, legs, thighs and drumsticks) weights were taken. The gastrointestinal tract (GIT) organs (esophagus, proventriculus, gizzard, intestines and caeca) weights as well as the associated organs (heart and liver) weights were taken. Also lengths of GIT organs (esophagus, proventriculus, intestines and caeca) were taken as well. Chemical analysis of meat and manure were carried out. Some chemical and physical attributes of tibia bones were 
undertaken. Sensory attributes (taste, flavor, color and tenderness) evaluation of breast meat was done using the sensory description technique with trained panelists. The Mortality of birds was recorded and the mortality rate was calculated weekly basis and as an overall at the end of the experiment. The production costs and returns were calculated in Sudanese Pounds to get the total revenue by subtracting the total costs from the total returns.

\section{Statistical analysis}

The statistical analysis of the experimental data was performed according to the completely randomized design (CRD), using the method of the general linear model (ANOVA). Differences between the experimental averages were calculated using Duncan (1955) multiple range tests at (0.05) probability. The statistical analysis program (SAS 2003) was used. Data were subjected to analysis of variance with the following equation:

$\mathrm{Yij}=\mu+\mathrm{Ti}+\varepsilon \mathrm{ij}$

where: $\mathrm{Yij}=$ observation.

$\mu=$ population average.

$\mathrm{Ti}=$ diet effect $(\mathrm{i}=1$ to 3$)$.

$\varepsilon \mathrm{ij}=$ residual error

\section{RESULTS AND DISCUSSION Broiler performance}

Results on chickens' performance are shown in Table 2. There were significant $(\mathrm{P} \leq 0.05)$ differences live body weight (BW) and body weight gain (BWG) were $\mathrm{T} 3$ and $\mathrm{T} 2$ recorded the higher weights, respectively. However, the control group significantly $(\mathrm{P} \leq 0.05)$ recorded the highest feed consumption (FC) during the entire experimental period and T3 had the lowest FC. The overall feed conversion ratio (FCR) was significantly $(\mathrm{P} \leq 0.05)$ the best for $\mathrm{T} 3$ and
T2, respectively compared to T1 (Table 2 ). These findings are on line with some authors (Nardelli et al., 2018; Walters et al., 2019; Abo Omar and Sabha 2020). The findings of these authors confirmed that phytase supplemented diets containing low levels of $\mathrm{P}$ had a positive effect on performance of broiler chickens. However, these results were on accord with that of Angel et al. (2005) who reported no differences among BW of broilers fed the NRC (1994) recommended $\mathrm{P}$ level and that fed less $\mathrm{P}$ but with added phytase.

There is no significant difference $(\mathrm{P} \geq 0.05)$ in overall mortality rate among different treatments (Table 2).

\section{Gastrointestinal tracts (GIT)}

Table 3 shows no significant $(P \geq 0.05)$ differences in some GIT organs (gizzard and heart) weights among all treatments. However, there were significant $(\mathrm{P} \leq 0.05)$ differences in other GIT organs (esophagus, proventriculus, small and large intestine, liver and caeca) and abdominal fat pads. These results confirm better use of nutrients that is clear in improved body weights and better FCR in broiler fed diets supplemented with phytase enzyme. There were significant $(\mathrm{P} \leq 0.05)$ differences in lengths of proventriculus and small and large intestines. However, there were. No significant $(\mathrm{P} \geq 0.05)$ differences were found between lengths of esophagus, caeca (Table 3). These results are in line with those of Amer (2014).

\section{Carcass characteristics}

Table 4 presents some carcass characteristics of broiler fed on diets (with or without added DCP), supplemented with phytase. There were significant $(\mathrm{P} \leq 0.05)$ differences in live body weight, hot and cold carcass. The 


\section{phytase; broiler performance; di-calcium phosphate; economic appraisal.}

weights of the different parts (breast, whole leg, thigh, drumstick and wing) and dressing percentage, showed significant $(\mathrm{P} \leq 0.05)$ differences among different treatments, where $\mathrm{T} 3$ reported the best results. The results obtained herein are in good agreement with those of Amer, (2014) who reported significant $(\mathrm{P} \leq 0.05)$ differences among different treatments' weights of breast, thigh, drumstick and wing at six weeks of age when using diets low in $\mathrm{P}$ with added phytase. These findings are in accordance with that of Abo Omar, and Sabha (2020), who showed that phytase supplementation significantly $(\mathrm{P} \leq 0.05)$, increased the percentages of most carcass values of diets deficient in $P$.

Effect of phytase enzyme with or without DCP on breast meat chemical properties (DM, Ash, EE, Ca and P) percentages are presented in Table 4. There were significant $(\mathrm{P} \leq 0.05)$ differences between treatments, where T3 had the best results followed by $\mathrm{T} 2$ and $\mathrm{T} 1$ (control) respectively. These findings agree with those of Manobhavan et al. (2016) and Vidyasagar, et al. (2019). As shown in Table 4 there were no significant $(\mathrm{P} \geq 0.05)$ differences in meat sensory evaluation (taste, flavor color and tenderness) of the breast muscle. These results agree with the findings reported with previous authors (Elshib and Mukhtar (2016) who ound that sensory characteristics of the breast muscle did not show a significant difference $(\mathrm{P}<0.05)$ between dietary treatments supplemented with phytase.

\section{Physical properties and chemical composition of tibia bone}

As shown in Table 5 there were significant $(\mathrm{P} \leq 0.05) \quad$ differences in weights, lengths of the tibia bones and thicknesses of the medial wall (TMW), thickness of the lateral wall (TLW) and the medullary canal diameter (MCD). The highest thicknesses were recorded in $\mathrm{T} 3$ and $\mathrm{T} 2$ respectively, where $\mathrm{T} 1$ (control) recorded the lowest weights. As shown in Table 5 there were significant $(\mathrm{P} \leq 0.05)$ differences in tibia bone chemical properties (DM, Ash, Ca and $\mathrm{P}$ ) percentages among different treatments where T3 scored the best results, followed by T2. However, T1 reported the lowest results. These findings are in line with those of some authors (El-Sherbiny et al. 2010; Walters et al., 2019 and Vidyasagar, et al., 2019). They concluded that phytase supplementation to low $\mathrm{P}$ diets increased the mineral contents of tibia bone. The same conclusion had been reported by Karimi et al. (2011), Chung et al. (2013) and Sreeja et al. (2018) who showed that using broiler diets with low levels of monohydrate $\mathrm{P}$ and phytase might increase dietary utilization of $\mathrm{P}$ without changes in performance and quality of bones.

\section{Manure chemical properties}

Manure chemical properties (DM, Ash, $\mathrm{Ca}$ and $\mathrm{P}$ ) percentages are presented in Figure 1. There were significant $(\mathrm{P} \leq 0.05)$ differences among different treatments where (T1) the control treatment recorded the highest percentage value for chemical properties (DM, Ash, $\mathrm{Ca}$ and $\mathrm{P}$ ). However, (T3) recorded the lowest percentages. These results are consistent with previous studies of El-Sherbiny et al. (2010), who reported that birds excrete more than half of phosphorus and nitrogen they consume when using phytase with low P diets. They concluded that reduction of dietary $\mathrm{P}$ and the use of phytase enzyme can be used to limit the 
Madyan M. A. Alshamiri ${ }^{1}$ et al.

quantity of $\mathrm{P}$ excretion from broilers chickens, which will reduce impact on environmental pollution. The use of enzymes in poultry diets improves digestibility and availability of certain nutrients, mainly $\mathrm{P}, \mathrm{N}, \mathrm{CA}, \mathrm{C}$ and $\mathrm{Zn}$. This diminishes their presence in excreta and their deposition to the soil which will avoid environmental pollution. Coppedge, (2010) explained that to increase $\mathrm{P}$ bioavailability from phytate, use increased levels of phytase. These results as well in good agreement with Daniel et al. (2018) who reported that inclusion of phytase resulted in decreased fecal P levels, reducing the environmental pollution.

\section{Economic appraisal}

Figure (2) shows the economical appraisal of this experiment on the basis of input costs, returns and revenues. There was a clear effect of phytase enzyme at $1500 \mathrm{FTU} / \mathrm{Kg}$ level without adding DCP to the diet of birds on meat cost. Significant $(P<0.05)$ differences were recorded between the different treatments. T3 had the lowest cost and highest return. These results are consistent with previous authors (Selle, and Ravindran 2007; Coppedge, 2010; Scholey et al. 2018). They showed that phytase supplementation helps in reducing levels of inorganic $\mathrm{P}$ in broiler diets leading to decreased expenses without affecting broiler performance. These results are also in accordance with those of Al-Harthi (2020) who concluded supplementation of phytase to olive cake diets produced the highest economic efficiency.

\section{CONCLUSION}

It can be concluded that using phytase up to $1500 \mathrm{FTU} / \mathrm{Kg}$ feed without adding dicalcium phosphate to broiler diets is beneficial in terms of good performance, returns and hygienic environment. 
phytase; broiler performance; di-calcium phosphate; economic appraisal.

Table (1): Feed ingredients and chemical composition of starter and finisher diets

\begin{tabular}{|l|c|c|c|c|c|c|}
\hline \multirow{2}{*}{ Ingredients } & \multicolumn{3}{|c|}{ Starter Diet (2nd-3rd } & \multicolumn{2}{c}{$\begin{array}{l}\text { inisher } \\
\text { week) }\end{array}$} & \multicolumn{2}{c|}{ Diet } & (4th-6th \\
\cline { 2 - 7 } & T1 & T2 & T3 & T1 & T2 & T3 \\
\hline Sorghum & 56.5 & 57.5 & 57.6 & 58.6 & 59.4 & 59.5 \\
Pea nut cake & 36 & 37 & 37 & 31 & 32 & 32 \\
Bro-Con* & 5 & 3 & 3 & 5 & 3 & 3 \\
Vegetable Oil & 0 & 0 & 0 & 2.5 & 2.5 & 2.5 \\
L- Lysine & 0.2 & 0.2 & 0.2 & 0.2 & 0.2 & 0.2 \\
Methionine & 0.1 & 0.1 & 0.1 & 0.1 & 0.1 & 0.1 \\
Premix & 0.5 & 0.5 & 0.5 & 0.5 & 0.5 & 0.5 \\
Oyster shell & 0.9 & 0.9 & 0.9 & 1.3 & 1.5 & 1.5 \\
Salt & 0.3 & 0.3 & 0.3 & 0.3 & 0.3 & 0.3 \\
Coline chloride & 0.2 & 0.2 & 0.2 & 0.2 & 0.2 & 0.2 \\
Antioxident and antifungal & 0.2 & 0.2 & 0.2 & 0.2 & 0.2 & 0.2 \\
Di-Calcium phosphate & 0.1 & 0.1 & 0 & 0.1 & 0.1 & 0 \\
Phytase U/Kg & 0 & 1500 & 1500 & 0 & 1500 & 1500 \\
Total & 100 & 100 & 100 & 100 & 100 & 100 \\
\hline Chemical composition & \multicolumn{5}{|l}{} \\
\hline CP \% & 22.2 & 22.1 & 22.1 & 20.3 & 20.2 & 20.2 \\
EE\% & 4.9 & 4.97 & 4.97 & 5.8 & 5.83 & 5.83 \\
CF \% & 5.8 & 5.8 & 5.8 & 5.3 & 5.3 & 5.3 \\
Ca \% & 1.1 & 0.9 & 0.9 & 1.2 & 1.1 & 1.1 \\
Total P \% & 0.5 & 0.41 & 0.31 & 0.5 & 0.39 & 0.29 \\
Available P\% & 0.39 & 0.29 & 0.19 & 0.39 & 0.28 & 0.17 \\
Lysine \% & 1 & 0.9 & 0.9 & 0.93 & 0.85 & 0.85 \\
Methi+Cysti\% & 0.85 & 0.76 & 0.76 & 0.8 & 0.72 & 0.72 \\
Methionine \% & 0.55 & 0.47 & 0.47 & 0.57 & 0.45 & 0.5 \\
ME kcal/kg** & 3097 & 3121 & 3124 & 3218 & 3235 & 2338 \\
Phytase U/Kg & 0 & 1500 & 1500 & 0 & 1500 & 1500 \\
\hline
\end{tabular}

* Super concentrate contains the following: $35 \%$ CP, $2 \%$ EE, $4 \%$ CF, $10 \%$ calcium, $4.5 \%$ available phosphorus, $5.7 \%$ lysine, $4.5 \%$ methionine and $4.9 \%$ methionine + cystine. ME 2000 $\mathrm{kcal} / \mathrm{kg}, 2.6 \%$ Sodium with added vitamins and minerals.

** Metabolizable energy ( $\mathrm{ME} \mathrm{Kcal} / \mathrm{kg}$ ) was calculated according to the formula derived by Lodhi et al. (1976). ME kcal $/ \mathrm{kg}=32.95$ (\% crude protein $+\%$ ether extract $\times 2.25+\%$ available carbohydrate) $-29 \cdot 20$. 
Table (2): The effect of phytase enzyme with or without added DCP on performance of broiler chicken

\begin{tabular}{|l|c|c|c|c|c|}
\hline \multirow{2}{*}{\multicolumn{1}{c|}{ Age }} & \multicolumn{3}{|c|}{ Treatments } & \multirow{2}{*}{ C.V. } & \multirow{2}{*}{ P } \\
\cline { 2 - 5 } & T1 & T2 & T3 & 0 & NS \\
\hline Initial body weight & $40 \pm 0$ & & $40 \pm 0$ & 0 & $* 2$ \\
Final body weight & $2115^{\mathrm{c}} \pm 3.1$ & $2260^{\mathrm{b}} \pm 2.8$ & $2277^{\mathrm{a}} \pm 2$ & 0.2 & $* *$ \\
Total body weight gain & $2075^{\mathrm{c}} \pm 0.3$ & $2220^{\mathrm{b}} \pm 0.8$ & $2237^{\mathrm{a}} \pm 0.3$ & 0.2 & $* *$ \\
Total feed consumption & $3632^{\mathrm{a}} \pm 6$ & $3538^{\mathrm{b}} \pm 5$ & $3479^{\mathrm{c}} \pm 5.6$ & 0.3 & $* *$ \\
Overall feed conversion ratio & $1.75^{\mathrm{a}} \pm 0.001$ & $1.59^{\mathrm{b}} \pm 0.001$ & $1.56^{\mathrm{c}} \pm 0.0009$ & 0.9 & $* *$ \\
Mortality rate & $2.8 \pm 0.6$ & $2.8 \pm 0.5$ & $0.0 \pm 0.0$ & 8.3 & NS \\
\hline
\end{tabular}

antity rate

$2.8 \pm 0.6$

$2.8 \pm 0.5$

respectively Means in row followed by the same letter are not significantly different at $\mathrm{P}=0.05$, according to Duncan's (1955) Multiple Range Test. $\mathrm{CV}=$ coefficient of variation. $\mathrm{P}=$ probability. 
Table (3): The effect of phytase enzyme with or without added DCP on the gastrointestinal (GIT) weights (gm) and lengths (cm)

\begin{tabular}{|c|c|c|c|c|c|}
\hline \multirow{2}{*}{ Parameters } & \multicolumn{3}{|c|}{ Treatments } & \multirow{2}{*}{$\begin{array}{c}\text { C.V. } \\
\%\end{array}$} & \multirow{2}{*}{$\mathbf{P}$} \\
\hline & T1 & $\mathbf{T 2}$ & T3 & & \\
\hline Esophagus & $8.1^{b} \pm 0.03$ & $8.4^{\mathrm{a}} \pm 0.03$ & $8.4^{\mathrm{a}} \pm 0.03$ & 0.6 & $*$ \\
\hline Gizzard & $34.7 \pm 0.9$ & $36.7 \pm 1.4$ & $37.0 \pm 1.1$ & 5 & NS \\
\hline Small + large Intestines & $97.0^{b} \pm 1.8$ & $101.7^{\mathrm{ab}} \pm 0.7$ & $105.3^{\mathrm{a}} \pm 1.7$ & 2.9 & $*$ \\
\hline Liver & $41.7^{\mathrm{b}} \pm 1.3$ & $49.3^{\mathrm{a}} \pm 1.2$ & $50.3^{\mathrm{a}} \pm 1.4$ & 3.7 & $* *$ \\
\hline Abdominal fat pad & $28.0 \pm 0.6$ & $26.0 \pm 2.1$ & $22.7 \pm 1.2$ & 3.0 & $*$ \\
\hline \multicolumn{6}{|l|}{ Lengths (cm) } \\
\hline Esophagus & $18.6 \pm 0.03$ & $19.2 \pm 0.01$ & $19.5 \pm 0.01$ & 2.3 & NS \\
\hline Proventriculus & $3.7^{\mathrm{b}} \pm 0.1$ & $4.2^{\mathrm{a}} \pm 0.03$ & $4.3^{\mathrm{a}} \pm 0.08$ & 3.1 & $*$ \\
\hline Caeca & $20.3 \pm 0.3$ & $21.3 \pm 0.8$ & $21.3 \pm 0.8$ & 4.2 & NS \\
\hline Small + large Intestines & $216.7^{\mathrm{b}} \pm 1.8$ & $221.3^{\mathrm{ab}} \pm 1.2$ & $223.0^{\mathrm{a}} \pm 1.5$ & 1.1 & $* *$ \\
\hline
\end{tabular}

Footnote remains the same as that of Table 2. 
Madyan M. A. Alshamiri ${ }^{1}$ et al.

Table (4): The effect of phytase with or without added DCP on carcass characteristics

\begin{tabular}{|c|c|c|c|c|c|}
\hline \multirow{2}{*}{ Parameters } & \multicolumn{3}{|c|}{ Treatments } & \multirow{2}{*}{$\underset{\%}{\text { C.V. }}$} & \multirow{2}{*}{$\mathbf{P}$} \\
\hline & T1 & $\mathbf{T 2}$ & T3 & & \\
\hline Live body & $2115.7^{\mathrm{c}} \pm 1.8$ & $2259.7^{b} \pm 1.4$ & $2276.6^{\mathrm{a}} \pm 0.7$ & 0.07 & $* *$ \\
\hline \multicolumn{6}{|c|}{ Weight in grams } \\
\hline Carcass (Hot) & $1574.7^{\mathrm{c}} \pm 1.7$ & $1705.7^{b} \pm 1.2$ & $1727.0^{\mathrm{c}} \pm 1.0$ & 0.13 & $* *$ \\
\hline Breast meat & $374.0^{c} \pm 0.5$ & $443.3^{\mathrm{b}} \pm 1.6$ & $456.7^{\mathrm{a}} \pm 1.6$ & 3.7 & $* *$ \\
\hline Whole leg & $218.7^{\mathrm{c}} \pm 0.8$ & $240.7^{\mathrm{b}} \pm 1.3$ & $247.6^{\mathrm{a}} \pm 0.8$ & 0.9 & $* *$ \\
\hline Thigh & $115.0^{c} \pm 0.5$ & $130.7^{\mathrm{b}} \pm 1.2$ & $134.6^{\mathrm{a}} \pm 0.8$ & 1.2 & $* *$ \\
\hline Drumstick & $103.7^{b} \pm 0.3$ & $110.0^{\mathrm{a}} \pm 1.1$ & $110.2^{\mathrm{a}} \pm 1.1$ & 3.0 & $* *$ \\
\hline Wing & $80.7^{\mathrm{b}} \pm 1.3$ & $85.3^{\mathrm{a}} \pm 1.4$ & $88.7^{\mathrm{a}} \pm 0.8$ & 2.5 & $*$ \\
\hline Dressing \% & $74.4^{c} \pm 0.04$ & $75.5^{b} \pm 0.04$ & $75.9^{\mathrm{a}} \pm 0.03$ & 0.09 & $* *$ \\
\hline \multicolumn{6}{|c|}{ Breast meat chemical properties \% } \\
\hline $\mathrm{DM}$ & $30.1^{\mathrm{c}} \pm 0.2$ & $35.4^{\mathrm{b}} \pm 0.5$ & $37.4^{\mathrm{a}} \pm 0.4$ & 1.9 & $* *$ \\
\hline Ash & $1.2^{\mathrm{b}} \pm 0.08$ & $1.8^{\mathrm{a}} \pm 0.05$ & $2.0^{\mathrm{a}} \pm 0.4$ & 4.8 & $* *$ \\
\hline $\mathrm{EE}$ & $1.9^{\mathrm{b}} \pm 0.05$ & $3.2^{\mathrm{ab}} \pm 0.1$ & $3.8^{\mathrm{a}} \pm 0.6$ & 5.3 & $*$ \\
\hline $\mathrm{Ca}$ & $0.8^{\mathrm{c}} \pm 0.05$ & $1.2^{\mathrm{b}} \pm 0.05$ & $1.8^{\mathrm{a}} \pm 0.1$ & 4 & $* *$ \\
\hline $\mathrm{P}$ & $0.4^{c} \pm 0.03$ & $0.7^{b} \pm 0.03$ & $0.9^{\mathrm{a}} \pm 0.03$ & 5.2 & $* *$ \\
\hline \multicolumn{6}{|c|}{ Breast meat sensory evaluation rate \% } \\
\hline Taste & $26 \pm 0.2$ & $36 \pm 0.3$ & $35 \pm 0.1$ & 10.0 & NS \\
\hline Flavor & $23 \pm 0.2$ & $28 \pm 0.2$ & $30 \pm 0.1$ & 11.0 & NS \\
\hline Color & $29 \pm 0.2$ & $32 \pm 0.2$ & $33 \pm 0.2$ & 11.1 & NS \\
\hline Tenderness & $33 \pm 0.1$ & $36 \pm 0.1$ & $38 \pm 0.1$ & 10.0 & NS \\
\hline
\end{tabular}

Footnote remains the same as that of Table 2.

Table (5): The effect of phytase with or without added DCP on some physical properties and chemical composition of tibia bone

\begin{tabular}{|l|c|c|c|c|c|}
\hline \multicolumn{1}{|c|}{ Parameters } & Treatments & \multirow{2}{*}{ C.V. \% } & \multirow{2}{*}{ P } \\
\hline \multicolumn{7}{|c|}{ T2 } & T3 & & \\
\hline \multicolumn{7}{|c|}{ Tibia bone some physical properties } \\
\hline Tibia weight $(\mathrm{g})$ & $11.5^{\mathrm{c}} \pm 0.05$ & $12.7^{\mathrm{b}} \pm 0.1$ & $13.1^{\mathrm{a}} \pm 0.05$ & 1.0 & $* *$ \\
Tibia length (cm) & $9.0^{\mathrm{c}} \pm 0.05$ & $10.0^{\mathrm{b}} \pm 0.05$ & $10.3^{\mathrm{a}} \pm 0.1$ & 1.1 & $* *$ \\
TMW (mm) $*$ & $1.0^{\mathrm{b}} \pm 0.05$ & $1.2^{\mathrm{ab}} \pm 0.02$ & $1.3^{\mathrm{a}} \pm 0.02$ & 4.2 & $* *$ \\
TLW (mm)** & $1.8^{\mathrm{c}} \pm 0.02$ & $2.4^{\mathrm{b}} \pm 0.04$ & $2.5^{\mathrm{a}} \pm 0.01$ & 2.0 & $* *$ \\
MCD (mm)** & $7.2^{\mathrm{b}} \pm 0.06$ & $7.8^{\mathrm{ab}} \pm 0.05$ & $8.2^{\mathrm{a}} \pm 0.2$ & 2.7 & $*$ \\
\hline \multicolumn{7}{|l|}{ Tibia bone chemical composition } \\
\hline DM \% & $88.1^{\mathrm{c}} \pm 0.06$ & $91.3^{\mathrm{b}} \pm 0.06$ & $93.5^{\mathrm{a}} \pm 0.5$ & 0.3 & $* *$ \\
Ash \% & $48.0^{\mathrm{c}} \pm 0.09$ & $52.8^{\mathrm{b}} \pm 0.3$ & $55.9^{\mathrm{a}} \pm 0.05$ & 0.5 & $* *$ \\
Ca\% & $16.7^{\mathrm{b}} \pm 0.09$ & $19.2^{\mathrm{a}} \pm 0.06$ & $20.5^{\mathrm{a}} \pm 0.05$ & 0.6 & $*$ \\
P\% & $8.1^{\mathrm{c}} \pm 0.06$ & $9.2^{\mathrm{b}} \pm 0.06$ & $10.9^{\mathrm{a}} \pm 0.08$ & 0.4 & $* *$ \\
\hline
\end{tabular}

Footnote remains the same as that of Table 2 .

$*$ TMW $=$ thicknesses of the medial wall. $* *$ TLW $=$ thickness of the lateral wall.

$* * * \mathrm{MCD}=$ medullary canal diameter. 
phytase; broiler performance; di-calcium phosphate; economic appraisal.
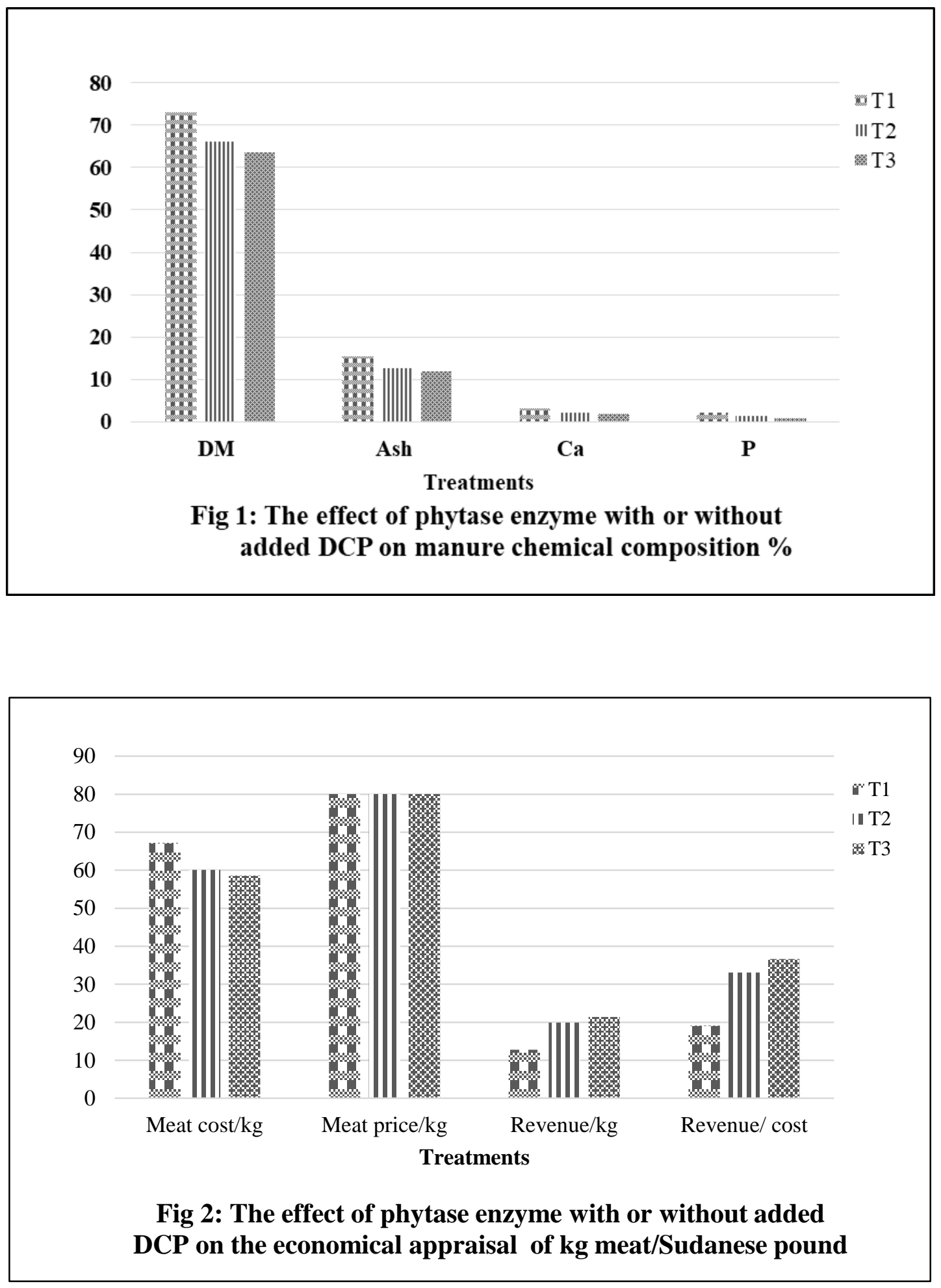
Madyan M. A. Alshamiri ${ }^{1}$ et al.

\section{REFERENCES}

Abo Omar, J. M. and Sabha, R. 2009. Effects of phytase on broilers performance and body status of phosphorus. Hebron University Research Journal-A (Natural Sciences). 4: $55-66$.

Alagawany, M. and Attia, A. 2015. Effects of feeding sugar beet pulp and avizyme supplementation on performance, egg quality, nutrient digestion and nitrogen balance of laying Japanese quail. Avian Biol. Res., 8: 79-88.

Al-Harthi, M.A.; Attia, Y.A.; Ali S. ElShafey, A.S. and Elgandy, M.F. 2020. Impact of phytase on improving the utilisation of pelleted broiler diets containing olive by-products, Ita. J. of An. Sci, 19: 310-318,

Ali, S.A,M.; Abdalla, H.O. and Mahgoub, I.M. 2011. Effect of slaughtering method on the keeping quality of broiler chickens' meat. Egypt. Poult. Sci. 31: 727-736.

Amer, A. M. 2014. Effect of phytase enzyme supplementation in deficient phosphate diet on broiler performance and some blood traits. International Journal of Science Nature, 5: 341-345, ISSN 2229 - 6441.

Angel, R.; Saylor, W. W.; Dhandu, A. S.; Powers, W. and Applegate, T. J. 2000. Effect of dietary phosphorus, phytase and 25-hydroxycholecalciferol on performance of broiler chickens grown in floor pens. Poult. Sci., 84: 1031-1044.

AOAC, Method 2000.12: Phytase activity in feed: colorimetric enzymatic method, in Official Methods of Analysis of AOAC 283 International, $17^{\text {th }} \mathrm{Ed}$. Association of Official Analytical Chemists, Arlington. ISBN-10 093558467-6
Attia, Y.A.; Bovera, F.; Iannaccone, F.; Al-Harthi, M.A.; Alaqil, A.A.; Zeweil, H.S. and Mansour, A.E. 2020. Microbial and fungal phytases can affect growth performance, nutrient digestibility and blood profile of broilers fed different levels of nonphytic phosphorous. Animals, 30:580592.

https://doi.org/10.3390/ani10040580

PMID: 32235511; PMCID:
PMC7222415.

Coppedge, J. R. 2010. Enhancement of growth performance and bone mineralization in market broilers through dietary enzymes. Major Subject: Poultry Science https://core.ac.uk/download/pdf/14719 7223.

Chung, T.K.; Rutherfurd, S.M.; Thomas, D.V. and Moughan, P.J. 2013. Effect of two microbial phytases on mineral availability and retention and bone mineral density in lowphosphorus diets for broilers. British Poultry Science 54: 362-373. Doi.org/10.1080/00071668.2013.7839 02

Ciurescu, G.; Vasilachi, A. and Grosu, H. 2020. Efficacy of microbial phytase on growth performance, carcass traits, bone mineralization and blood biochemistry parameters in broiler turkeys fed raw chickpea (Cicer arietinum L., cv. Burnas) diets. J. Appl. Poult. Res. 29:171-184 https://doi.org/10.1016/j.japr.2019.10. $\underline{004}$

Daniel, J. D.; Nor, H. A.; Nur, I. W. A.; Jennifer E.; Sarah A. Y.; Roslinda A.; Vickpasubathysiwa S.; Dalia S. and Hesham E. 2018. Current and future applications of phytases in poultry industry: A critical 
phytase; broiler performance; di-calcium phosphate; economic appraisal.

review. J Adv VetBio Sci Tech. 3(3): 65-74. DOI: $10.31797 /$ vetbio.455687

Duncan D 1955. Multiple Range and Multiple F Tests. Biometrics 11: 1-42

El-Sherbiny, A. E.; Hassan, H. M. A.; Abd-Elsamee, M. O.; Samy, A. and Mohamed, M. A. 2010. Performance, Bone Parameters and Phosphorus Excretion of Broilers Fed Low Phosphorus Diets Supplemented with Phytase from 23 to 40 Days of Age. International Journal of Poultry Science 9 (10): 972-977, DOI: 10.3923/ijps.2010.972.977

Elshib RMH and Mukhtar MA, 2016. Effect of different levels of Roselle seed supplemented with commercial phytase enzyme on the performance of broiler chickens. World Journal of Pharmacy and Pharmaceutical Sciences 5: 2109-2118. https://doi.org/10.20959/wjpps20166$\underline{6976}$

Ennis, C.E; Jackson, M; Gutierrez, O; Cantley, $S$ ad Wamsley, K.G.S. 2020. Phytase and carbohydrase inclusion strategies to explore synergy within low-energy diets to optimize 56-day male broiler performance and processing, J. of Appl. Poult. Res, 29: 1045-1067.

https://doi.org/10.1016/j.japr.2020.09. $\underline{013}$

Hughes, A. L.; Dahiya, J. P.; Wyatt, C. L. and Classen, H. L. 2009. Effect of quantum phytase on nutrient digestibility and bone ash in White Leghorn laying hens fed corn-soybean meal based diets. Poult. Sci., 88: 11911198. https://doi.org/10.3382/ps.2008$\underline{00233}$

Karimi, A.; Bedford, M. R.; Sadeghi, G.; Ghobadi, Z. 2011. Influence of dietary non-phytate phosphorus levels and phytase supplementation on the performance and bone characteristics of broilers. Brazilian Journal of Poultry Science. 13: 43-51. DOI: 10.1590/S1516-635X2011000100007

Khan, S. A.; Chaudhry, H. R.; Butt, Y. S.; Jameel, T. and Ahmad, F. 2013. The effect of phytase enzyme on the performance of broiler flock (a review). Poultry Science Journal, 1(2), 117-125. doi: 10.22069/psj.2013.1478

Lei, X. G. and Porres, J. M. 2003. Phytase enzymology, applications, and biotechnology. Biotechnology Letters 25: 1787-1794.

Lodhi G, Singh D and Ichhponani J, 1976. Variation in nutrient content of feeding stuffs rich in protein and reassessment of the Chemical method for metabolizable energy estimation for poultry. The Journal of Agricultural Science 86: 293-303. https://doi.org/10.1017/S0021859600 054757

Mondal, M. K.; Panda, S. and Biswas, P. 2007. Effect of microbial phytase in soybean meal based broiler diets containing low phosphorus. International Journal of Poultry Science 6: 201-206. DOI: 10.3923/ijps.2007.201.206

Manobhavan, M.; Elangovan, A. V.; Sridhar, M. D.; Shet, S.; Ajith, D. T.; Pal and Gowda, N. K. S. 2016. Effect of super dosing of phytase on growth performance, ileal digestibility and bone characteristics in broilers fed corn-soya-based diets. Journal of animal physiology and animal nutrition, 100: 93-100. DOI: 10.1111/jpn.12341

Nardelli, N. B. d.; Luciana, d. P. N.; David, H. d. O.; Antonio, A. P. G. J.; 
Madyan M. A. Alshamiri ${ }^{1}$ et al.

Eduardo, M. C. L.; Evelyn, C. d. O. And Paulo, B. R. 2018. Supplementation of fungal and/or bacterial phytase in broiler diets formulated with reduced phosphorus level and different calcium contents. Brazilian Journal of Animal Science. 47: 1561-1568. https://doi.org/10.1590/rbz472017029 7

N. R. C. 1994. Nutrient requirements of poultry. $9^{\text {th }}$ Ed. National Academy Press. Washington DC, USA.

Scholey, D. V.; Morgan, 1. N. K.; Riemensperger, A.; R. Hardy, R. and E. J. Burton, E. J. 2018. Effect of supplementation of phytase to diets low in inorganic phosphorus on growth performance and mineralization of broilers. Poultry Science 97:2435-2440 http://dx.doi.org/10.3382/ps/pey088

Selle, P. H. and Ravindran, V. 2007. Microbial phytase in poultry nutrition: A review. Anim Feed Sci Tech. 135:1-41. doi:10.1016/j.anifeedsci.2006.06.010.

Sreeja, A.; Divya, S.; Jyotirmoy, G.; Vaibhav B.A.; Karthik B.; Dintaran P. and Arumbackam V.E. 2018. Effect of immobilized fungal phytase on growth performance and bone traits of broilers fed with low dietary calcium and phosphorus. Veteri.
World, 11: 758-764. doi:10.14202/vetworld.2018.758-764

Srikanthithasan K.; Macelline S. P.; Wickramasuriya, S. S.; Tharangani,H.; Li,A.; Jayasena, D. D; Heo, J. M. 2020. Effects of adding phytase from Aspergillus niger to a low phosphorus diet on growth performance, tibia characteristics, phosphorus excretion, and meat quality of broilers 35 days after hatching. J. Poult Sci. 57:28-36. doi: 10.2141/jpsa.0180143. PMID: 32174762

Statistical analysis system (SAS) 2003. Statistical analysis system. User's Guide SAS/STA-t version, 8th Ed, SAS, Institute, Inc. New York, USA.

Vidyasagar; Jayanaik; Malathi, V.; Umashankar, B. C.; Prasad, C. K. and Sayyad, I. A. 2019. Influence of phytase supplementation on mineral retention, blood and bone minerals content in low phosphorus diet fed in Giriraja birds. Journal of Entomology and Zoology Studies. 2019; 7(1): 5862

Walters, H. G; Coelho, M.; Coufal. C.D. and Lee, J.T. 2019. Effects of increasing phytase inclusion levels on broiler performance, nutrient digestibility, and bone mineralization in low-phosphorus diets. J. of Appl. Poult. Res. 28: 1210-1225. 


\section{الملخص العربي \\ فعالية إضافة إنزيم الفيتيز إلي عليقة كتاكيت اللحم مع أو بدون ثنائي فوسفات الكالسبوم علي الأبي الأداء والقيمة الإقتصادية البه}

مدين محمد عائ الشميري' وسيده عوض محمدعلي وحاتم بدوي أحمد الخيرَ وحيدر عثمان عبد الله ‘

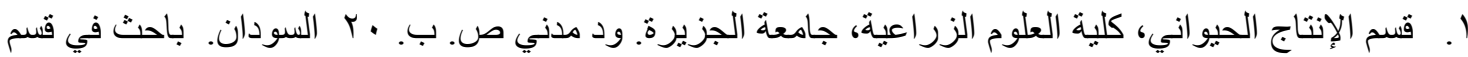

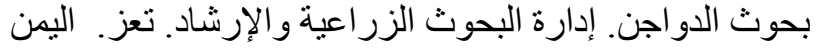

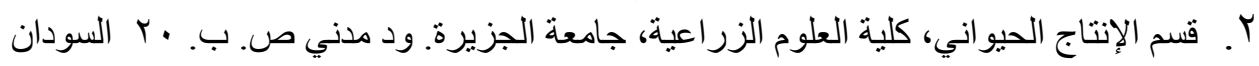

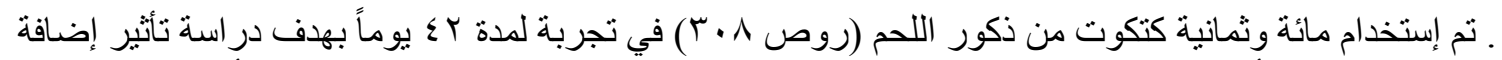

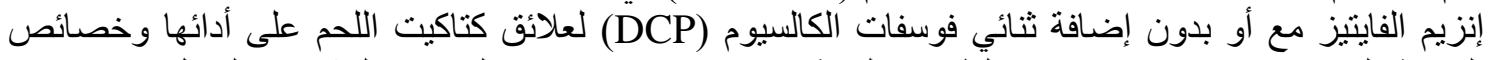

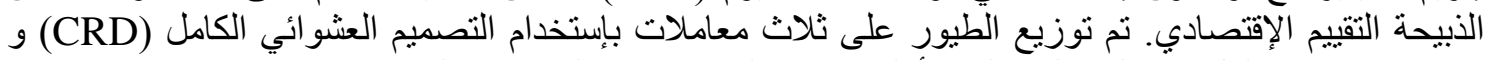

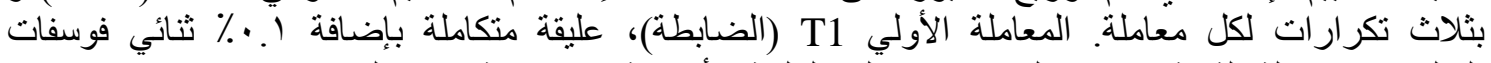

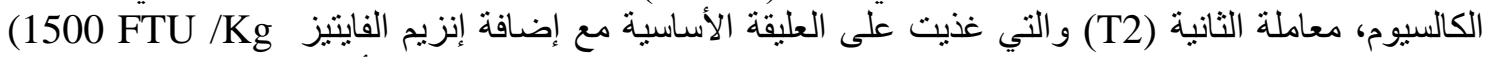

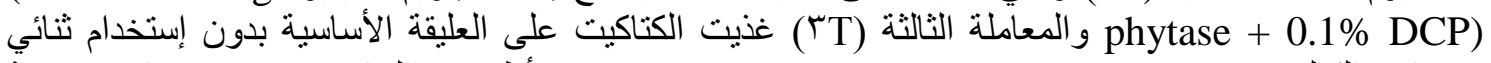

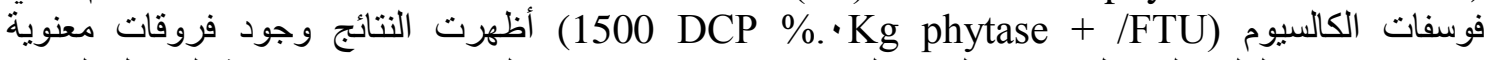

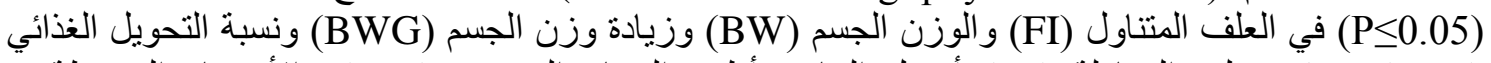

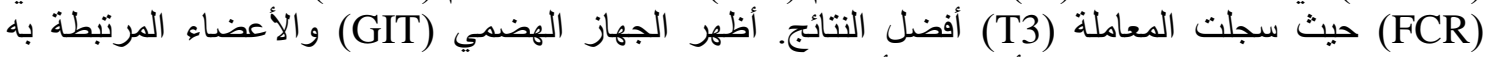
إختلافات معنوية (PR

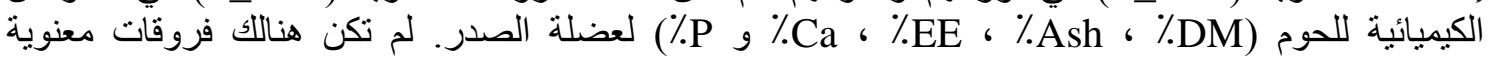

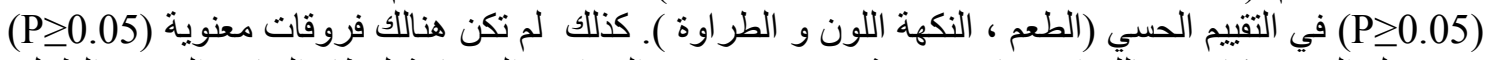

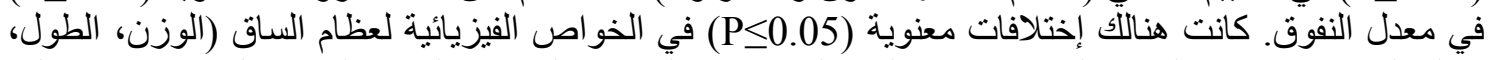

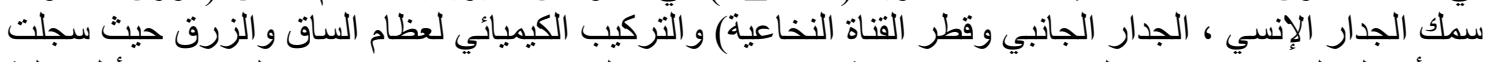

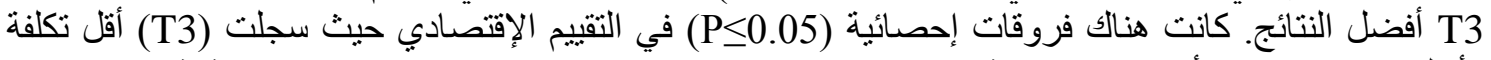

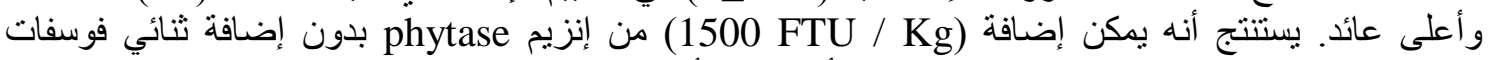
الكالسيوم إلى علائق كتاكيت اللحم للحصول على أداء جيد و أفضل عائد وتقليل التلوث البيئي 